\title{
FATIGUE BEHAVIOUR OF X70 STEEL IN CRUDE OIL
}

\section{VEDENJE JEKLA X70 PRI UTRUJANJU V SUROVI NAFTI}

\author{
L'ubomír Gajdoš ${ }^{1}$, Martin Šperl ${ }^{1}$, Jaroslav Bystrianský \\ ${ }^{1}$ Institute of Theoretical \& Applied Mechanics, Academy of Sciences of the Czech Republic, v.v.i., Department of Thin-Walled Structures, \\ Prosecká 25, Prague 9, 190 00, Czech Republic \\ ${ }^{2}$ Institute of Chemical Technology, Technická 5, Prague 6, 166 28, Czech Republic \\ gajdos@itam.cas.cz \\ Prejem rokopisa - received: 2014-02-25; sprejem za objavo - accepted for publication: 2014-04-10
}

doi:10.17222/mit.2014.041

\begin{abstract}
The fatigue properties of the X70 steel in crude oil and in the water separated from the crude-oil phase were tested, the stress-cycle-asymmetry ratio being $R=0$. As a reference, fatigue tests in air were also carried out. The fatigue specimens used were prepared from the Vohburg an der Donau - Nelahozeves (IKL) crude-oil pipeline after 13 years of exploitation. The tests were aimed at assessing the degree of degradation of the fatigue properties of this steel due to the environmental impacts typical for the crude-oil processing and transport. For added value, fatigue tests were also carried out in an alkaline solution on specimens prepared from a new pipe. The results of the tests showed that the fatigue properties of the steel in crude oil were slightly better than in air, but much poorer in the water separated from the crude-oil phase.

Keywords: corrosion fatigue, S-N curve, X70 steel, crude oil, separated water
\end{abstract}

Preizkušeno je bilo vedenje jekla X70 pri utrujanju v surovi nafti in v vodi, izločeni iz surove nafte, pri čemer je bilo razmerje asimetrije napetostnih ciklov $R=0$. Za primerjavo so bili izvršeni tudi preizkusi utrujanja na zraku. Uporabljeni vzorci za utrujanje so bili izrezani iz naftovoda Vohburg an der Donau - Nelahozeves (IKL) za surovo nafto po 13 letih obratovanja. Namen preizkusov je bila ocena stopnje degradacije zaradi vpliva okolja, značilnega za pridobivanje in transport surove nafte. Kot zanimivost so bili izvršeni tudi preizkusi utrujanja $v$ alkalni raztopini pri vzorcih iz novih cevi. Rezultati preizkusov so pokazali, da je vedenje jekla pri utrujanju v nafti nekaj boljše kot na zraku, vendar občutno slabše v vodi, izločeni iz surove nafte.

Ključne besede: korozijsko utrujanje, S-N-krivulja, jeklo X70, surova nafta, izločena voda

\section{INTRODUCTION}

The transportation of crude oil from a production site to a refinery and from the refinery to the oil consumers needs to be very safe because, in the event of an accident, an oil-spillage disaster endangers the natural environment and causes financial losses. Crude oil is transported by sea in tankers and on land by trucks, trains and pipelines. Tankers are generally subjected to the corrosive action of seawater, and studies of the effect of seawater on the fatigue properties of the steels used in ship structures are therefore very important ${ }^{1}$. No less important is the transportation of crude oil on land through the pipelines. In comparison with the trucks and trains used for transporting oil, in recent decades the pipelines have proved to be highly economical and very safe. A number of pipelines are currently under construction all over the world.

The crude-oil flow rate is not constant as it varies according to the demand for crude oil. The crude-oil pressure increases when the flow volume increases and vice versa. Based on the records obtained, the pressure fluctuation is about 7 bar. On average, there are ten pressure changes in the month. The pressure fluctuation may result in the corrosion fatigue of a pipeline wall and some of its parts become corrosive ${ }^{2}$. It is therefore useful and has become a matter of interest to examine the fatigue behaviour of the steel in contact with the transported crude oil. Naturally, it would be desirable to conduct the fatigue tests with the frequency of the stress changes of the same order as the frequency of the crude-oil pressure changes encountered in practice $\left(10^{-4}\right.$ $\mathrm{Hz}$ ), but this would require tests of unrealistic duration. It is more convenient to carry out ordinary resonant-frequency fatigue tests which, of course, cannot represent the actual corrosion-fatigue resistance of a crude-oil pipeline. Nevertheless, the results can be taken as informative data indicating relative fatigue-resistance values of the pipelines for various crude oils.

\section{FATIGUE TESTS}

The material used in the tests (X70) was taken from a real IKL oil pipeline, with an outside diameter of 711 $\mathrm{mm}$ and a wall thickness of $8.5 \mathrm{~mm}$, after the pipeline had been in operation for about 13 years. The steel contained mass fractions $(w / \%)$ C 0.18, Mn 1.3, Si 0.23, $\mathrm{P} 0.009$, S 0.021 , Ni 0.03 , and V 0.01 and its structure was bainitic with the bandings in the longitudinal direction. The static tensile properties in the hoop direction were as follows: the ultimate tensile strength $R_{\mathrm{m}}=610$ $\mathrm{MPa}$, the yield stress $R_{\mathrm{p} 0.2}=495 \mathrm{MPa}$, and the elongation at failure $A_{5}=31 \%$. This steel is designated as X70-A. 


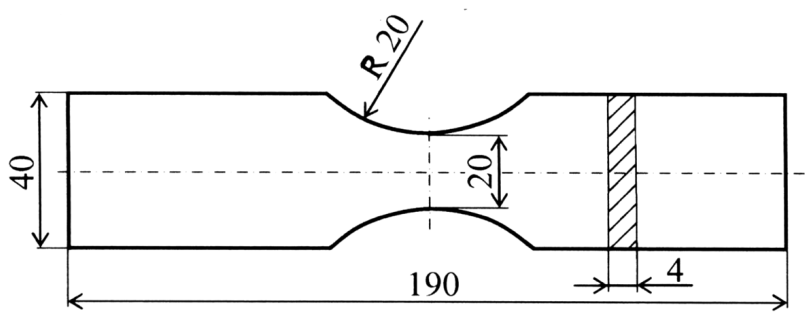

Figure 1: Fatigue specimen of varying width Slika 1: Vzorec za utrujanje $\mathrm{z}$ različno širino

For added value, fatigue tests were also carried out in an alkaline solution. They were performed on another steel sample of the same grade (X70), taken from a new pipe with a diameter of $508 \mathrm{~mm}$ and a wall thickness of $10 \mathrm{~mm}$. The static mechanical properties of this steel were as follows: $R_{\mathrm{m}}=625 \mathrm{MPa}, R_{\mathrm{p} 0.2}=500 \mathrm{MPa}$, and $A_{5}=24 \%$. In order to distinguish it from the steel taken from the pipeline, this steel was designated as X70-B.

The fatigue tests were performed in zero-to-tension loading with the resonance frequency of 130-133 Hz, using an Instron electromagnetic resonance fatigue machine, model 1603, with an automatic system for the mean-load control and with the maximum force level $F=$ $100 \mathrm{kN}$. Flat specimens of a varying width and a constant thickness were used in the tests (Figure 1).

The reference fatigue tests of X70-A were made in air, while the main fatigue tests were made in liquid

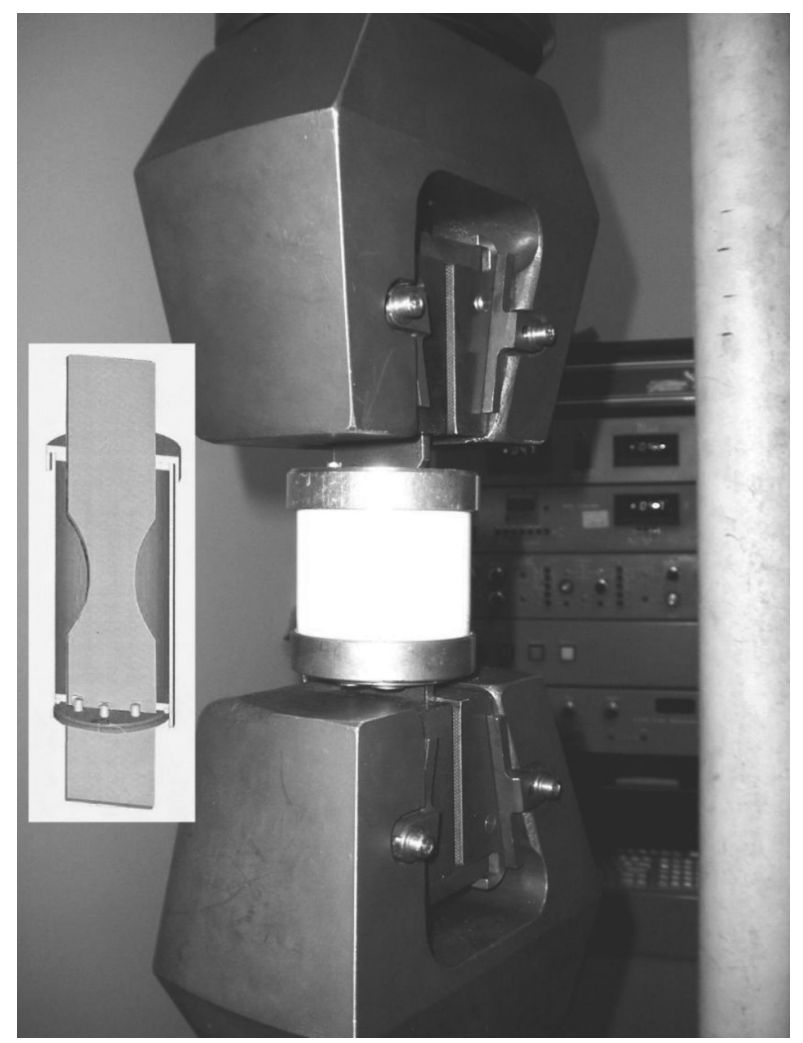

Figure 2: View of a specimen in a sealing cell, in the grips of the fatigue machine

Slika 2: Vzorec v zatesnjeni celici, vpet v čeljusti naprave za utrujanje environments: in crude oil and in the water separated from the crude-oil phase. The fatigue tests of the X70-B steel were made in a $1 \mathrm{~N}$ water alkaline solution of $\mathrm{Na}_{2} \mathrm{CO}_{3}$ and $\mathrm{NaHCO}_{3}$ in the ratio of $1: 1$ with $\mathrm{pH}=$ 9.325. ${ }^{3}$

In cooperation with the RCP Prague, a special sealing cell was developed for the fatigue tests in a liquid medium (Figure 2). The number of cycles to fracture $N_{\mathrm{f}}$ was determined as the number of the stress cycles that the resonance machine was able to exert without changing the set-up parameters. The relative sizes of the cracks at the instant when the machine was automatically stopped were approximately $0.25-0.4$ of the minimum width of a specimen.

The fatigue tests in the water phase separated from the crude oil (Vohburg-Nelahozeves) were, to some extent, specific since this environment is, in fact, a residue of the deposit water that is present, in small amounts, in the transmitted crude oil, either in an emulsified form or a dissolved form (in very small amounts) ${ }^{4}$. The chemical composition of separated water is shown in Table 1.

Table 1: Results of an analysis of the water phase Tabela 1: Rezultati analize vodne faze

\begin{tabular}{|l|c|c|}
\hline \multicolumn{1}{|c|}{$\mathrm{pH}$} & - & 7.0 \\
\hline specific conductivity & $\mathrm{mS} \mathrm{m}^{-1}$ & 2000 \\
\hline dissolved substances & $\mathrm{g} \mathrm{dm}^{-3}$ & 14 \\
\hline neutralization capacity $\left(\mathrm{KNK}_{4.5}\right)$ & $\mathrm{mmol} \mathrm{dm}^{-3}$ & 11 \\
\hline$\sum(\mathrm{Ca}+\mathrm{Mg})$ & $\mathrm{mmol} \mathrm{dm}^{-3}$ & 22 \\
\hline chlorides $\left(\mathrm{Cl}^{-}\right)$ & $\mathrm{g} \mathrm{dm}^{-3}$ & 8.1 \\
\hline sulphates $\left(\mathrm{SO}_{4}^{2-}\right)$ & $\mathrm{mg} \mathrm{dm}^{-3}$ & 31 \\
\hline oxygen $\left(15-25^{\circ} \mathrm{C}\right)$ & $\mathrm{mg} \mathrm{dm}^{-3}$ & $9.5-8.5$ \\
\hline
\end{tabular}

Before the actual fatigue tests, the water was left in contact with the air in order to saturate with oxygen (carbon dioxide). The oxygen amount corresponded to the saturation at the temperatures between $18{ }^{\circ} \mathrm{C}$ and $23{ }^{\circ} \mathrm{C}$.

\section{RESULTS OF THE FATIGUE TESTS}

All the results of the fatigue tests are presented in Figure 3. In addition to the curves pertaining to the X70-A steel specimens there is also an S-N curve obtained for the specimens from the X70-B steel. The level of the fatigue limit in zero-to-tension loading of the $\mathrm{X} 70$-A steel specimens is represented by a horizontal dashed line. It is taken as $0.6 R_{\mathrm{m}}{ }^{5}$ which, in this case, yields a magnitude of $366 \mathrm{MPa}$.

The figure shows that at the upper margin of the family of all the experimental points (indicating the best fatigue properties) there are triangles corresponding to crude oil and dark diamonds corresponding to the alkaline solution applied to the X70-B steel. In the bottom part of the family of the experimental points there are, with a big downward shift, light diamonds that relate to separated water. Slightly below the triangles 


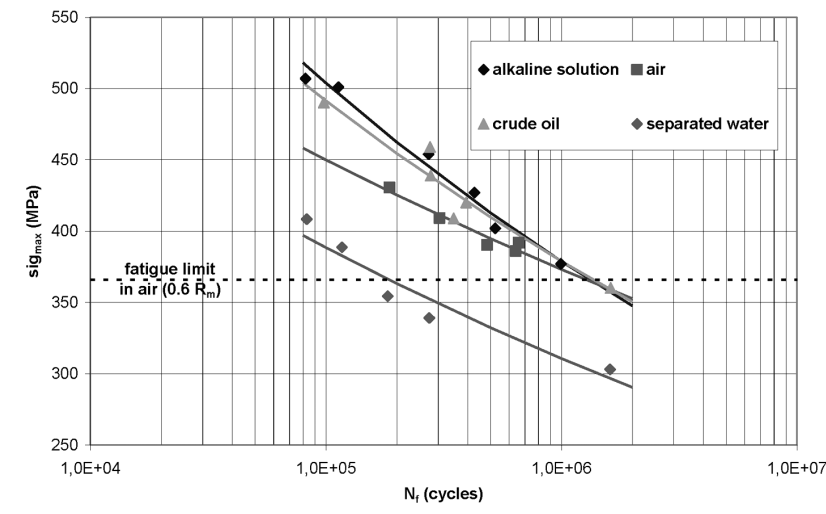

Figure 3: Aggregate presentation of the fatigue-test results Slika 3: Skupna predstavitev rezultatov preizkusov utrujanja

there are squares representing the results obtained in air. This shows that, in relation to the fatigue properties of the X70-A steel in air, the influence of crude oil appears to be non-aggressive, and it also follows that the effect of the alkaline solution on the X70-B steel appears to be very similar to the effect of crude oil on the X70-A steel. However, separated water has a very negative influence on the corrosion-fatigue properties of X70-A. Some of the results obtained for the X70-A steel are presented in ${ }^{6}$.

If the $\mathrm{S}-\mathrm{N}$ curve obtained in air is considered as a reference curve, then, according to this diagram, the crude-oil environment does not worsen the fatigue-corrosion resistance of the steel up to the fatigue limit region, i.e., up to a life of $2 \cdot 10^{6}$ cycles. The decrease in the maximum stress in a cycle with the number of cycles to fracture is, however, more rapid in crude oil than in air. As indicated by the position of the S-N curve for separated water in the diagram, the presence of separated water in crude oil leads to a considerable deterioration of the fatigue properties of the tested steel.

If we express the $\mathrm{S}-\mathrm{N}$ curves in the following form:

$$
\sigma_{\text {max }}=\frac{A}{\left(N_{\mathrm{f}}\right)^{\mathrm{b}}}
$$

constants $A$ and $b$ take the magnitudes shown in Table 2.

Table 2: Constants of the S-N curves for X70-A and X70-B steels Tabela 2: Konstanti krivulje S-N za jekli X70-A in X70-B

\begin{tabular}{|c|c|c|c|}
\hline environment & steel & $A$ & $b$ \\
\hline air & X70-A & 1147.4 & 0.0813 \\
\hline crude oil & X70-A & 1803.1 & 0.1129 \\
\hline separated water & X70-A & 1188.3 & 0.0971 \\
\hline alkaline solution & X70-B & 2098.3 & 0.1239 \\
\hline
\end{tabular}

As already specified, by identifying the fatigue limit with the maximum stress in a cycle for a life of $N_{\mathrm{f}}=2$. $10^{6}$ cycles, we can obtain probable fatigue limits in zero-to-tension loading. For the X70-A steel, these are: $\sigma_{\mathrm{f}}=353 \mathrm{MPa}$ in air, $\sigma_{\mathrm{f}}=350 \mathrm{MPa}$ in crude oil, and $\sigma_{\mathrm{f}}=$ $290 \mathrm{MPa}$ in separated water; and for the X70-B steel $\sigma_{\mathrm{f}}=$ $348 \mathrm{MPa}$ in the alkaline solution.

\section{DISCUSSION}

It was experimentally proved that crude oil has no negative effect on the fatigue properties of the X70-A steel. This contrasts with the effect of separated water, which exhibited corrosion aggressivity towards this steel. The corrosion aggressivity of separated water occurs due to its saturation with oxygen and a high amount of chlorides $^{7}$; however, the presence of acid carbonates in high concentrations reduces its aggressivity ${ }^{8}$. Under the conditions of a crude-oil pipeline, separated water can contain only a limited amount of oxygen, but under the conditions of long-term storage separated water can become saturated with air 9 . This environment can then be considered as the most aggressive possible environment ${ }^{10,11}$. In other words, due to a low $\mathrm{pH}$ value and a high $\left[c(\mathrm{Cl})+c\left(\mathrm{SO}_{4}\right)\right] / c\left(\mathrm{HCO}_{3}\right)$ ratio, separated water is an environment characterized by the highest chemical corrosion activity.

The effect of a crude-oil environment on the fatigue properties of steel is comparable to that of an inert environment since it manifests itself by preventing the surface from having contact with the oxygen in the air (fatigue tests in air).

The composition of the alkaline solution (its alkalinity and the presence of the $\mathrm{HCO}_{3}{ }^{-} / \mathrm{CO}_{3}{ }^{2-}$ system) leads to a passivation of the steel that, subsequently, results in a lower aggressivity of the solution.

\section{CONCLUSIONS}

1. A comparison of the fatigue properties of the $X 70$ steel in air and in crude oil has shown that crude oil had no aggressive effect on the steel in the sense of reducing its fatigue characteristics. The S-N curve for crude oil was above the reference S-N curve for air. A similar fatigue behaviour of the steel was exhibited when an alkaline solution was used, i.e., the corresponding S-N curves were very close to each other. However, quite a different situation was observed in the fatigue tests performed in separated water, which had an aggressive effect on the steel. The corresponding S-N curve was below the other curves, the decrease in terms of the cyclic load being 15-20\% with regard to the reference $\mathrm{S}-\mathrm{N}$ curve.

2. It can be stated that a crude-oil environment improves the fatigue properties of the steel up to the region of the fatigue limit, i.e., up to a life of $N_{\mathrm{f}}=2 \cdot 10^{6}$ cycles. The decrease in the maximum stress in a cycle with the increasing fatigue life is much more rapid in crude oil than in air. By contrast, separated water markedly worsens the fatigue properties. Thus, for example, when the specimens are cycled in crude oil with $\sigma_{\max }=380 \mathrm{MPa}$, their mean life is $N_{\mathrm{f}}=976500$ cycles; however, their life is reduced to $N_{\mathrm{f}}=125700$ cycles when they are cycled in separated water, i.e., their life is reduced by a factor of 
approximately 7.8. In this case the slope of the decrease in the cyclic stress is roughly the same as in air.

3. If the fatigue limit is considered as the maximum stress in a zero-to-tension cycle (the stress range) corresponding to a life of $N_{\mathrm{f}}=2 \cdot 10^{6}$ cycles, the fatigue limit for crude oil (350 $\mathrm{MPa})$ is practically the same as those for air (353 MPa) and alkaline solution (348 MPa). The smallest magnitude of the fatigue limit $(290 \mathrm{MPa})$ is found for separated water.

\section{Acknowledgements}

This work was supported by RVO: 68378297 and by the projects P105/10/2052 of the Grant Agency of the Czech Republic, and TE 02000162 of the Technological Agency of the Czech Republic.

\section{REFERENCES}

${ }^{1}$ V. Kasemi, A. Haxhiraj, Mater. Tehnol., 42 (2008) 6, 169-170

${ }^{2}$ L. Gajdoš et al., Structural Integrity of Pressure Pipelines, Transgas, a.s., Prague 2004, 137-160

${ }^{3}$ M. Šperl, Vliv korozního poškození na provozní spolehlivost plynovodních potrubí, (The Effect of Corrosion Damage on Operation Reliability of Gas Linepipes), Ph.D. Dissertation, Czech Technical University, Faculty of Transportation Sciences, Prague, 2008

${ }^{4}$ Z. A. Foroulis, Werkstoffe und Korrosion (Materials and Corrosion), 33 (1982) 3, 121-131, doi:10.1002/maco.19820330302

${ }^{5}$ P. Hopkins, Defect Assessment in Pipelines, APA Course, Prague, Czech Republic, 2001

${ }^{6}$ L. Gajdoš, M. Šperl, J. Bystrianský, J. Pressure Vessel Technol., 137 (2015) 5, 051401, doi:10.1115/1.4029659

${ }^{7}$ L. Garverick, Corrosion in the Petrochemical Industry, ASM International, 1994

${ }^{8}$ H. H. Uhlig, R. W. Revie, Corrosion and Corrosion Control, 3rd ed., Wiley-Interscience, New York, USA 1985, 415-441

${ }^{9}$ DIN 50930 (1993): Korrosion Metallischer Werkstoffe im Innern von Rohrleitungen, Behältern und Apparaten bei Korrosionsbelastung durch Wässer, Teile 1 bis 5, (Corrosion of Metallic Materials inside Pipelines, Vessels and Apparatuses Caused by Water, Parts 1-5), 1993

${ }^{10}$ R. Martínez-Palou et al., Journal of Petroleum Science and Engineering, 75 (2011) 3-4, 274-282, doi:10.1016/j.petrol.2010.11.020

${ }^{11}$ N. H. Abdurahman, Y. M. Rosli, N. H. Azhari, B. A. Hyder, Journal of Petroleum Science and Engineering, 90-91 (2012), 139-144, doi:10.1016/j.petrol.2012.04.025 